\title{
University Students' Perceptions on the Use of Google Translate: Problems and Solutions
}

\author{
https://doi.org/10.3991/ijet.v17i04.28179 \\ Anh Tuan Pham ${ }^{(\varpi)}$, Y Ngoc Nhu Nguyen, Loi Thang Tran, Khang Duy Huynh, \\ Ngan Thi Kim Le, Phuc Trong Huynh \\ FPT University, Can Tho, Vietnam \\ anhpt66efe.edu.vn
}

\begin{abstract}
Machine learning has globally become a trend in most educational settings. This study aims to explore students' perceptions when using Google Translate (GT) to support their learning as well as their problems and solutions from GT. With the participation of 250 university students at a private educational institution, a 5-point Likert-scale questionnaire and a semistructured interview were employed to examine how students perceived the use of GT in their learning process. The findings revealed that practically students had positive perceptions on GT's use in learning. Several major problems were recorded when they used GT, and some recommended solutions were also considered for improvement. Specifically, students utilized GT as a learning tool, particularly for language study, because of its useful features such as multilanguage translation, time saving, ease of use, and improving pronunciation. Although Google Translate has a number of advantages for students, several problems such as erroneous grammar and semantics on a frequent basis have led to misunderstanding of original words. As a result, students discovered that they needed to deal with these problems by double checking the results in a dictionary or other translation programs, as well as the help from a peer or supervisor. It is suggested that GT is a helpful machine translator, but students are encouraged to know how to make some judgement on its results for a better translation version.
\end{abstract}

Keywords-Google Translate, problems, solutions, perceptions, use

\section{Introduction}

Many individuals in the twenty-first century have developed sophisticated technology similar to what we have now. From the various modern technologies in the globe, laptops, mobile phones, tablets, and the Internet are the most often used by humans. There are so many things that can be accessed through mobile phones, especially smartphones, hence, it cannot be denied that humans have relied on technology, particularly mobile phones to promote communication and life mobility. Many applications that develop the convenience of instructions play a significant part in education. The Internet is fast evolving, and Google is currently the dominant player since it is 
the most widely used platform for public and educational purposes, and one of its most popular features is Google Translate, which is incorporated in one of Google's applications [1].

Various online Machine Translation (MT) services, such as Google Translate (GT), Bing Translator, and Yahoo Babel Fish, are currently available for Internet users and language learners. Google Translate is well-liked and ranked first among the most popular Machine Translation services. Google Translate can store over 200 billion words and provide users with the widest range of words and phrases to make it popular among students [2].

Google Translate can assist translators in completing their tasks more rapidly, but it also puts the users at risk. A large number of students now rely on GT, so the problems with GT services have not improved significantly. Furthermore, it is unclear why students who are aware of using GT can cause problems, but they have continued to use it till now [3]. The vast majority of students use GT in class, hence, the researchers wish to evaluate students' perceptions of using it in their study. Students' perceptions of the problems and solutions when using Google Translate are being sought by researchers.

The purpose of this study is to look into the use of Google Translate as a supplementary tool for helping learners to develop their language skills, as well as to examine the problems that arose when using GT and potential solutions to these problems through an analysis of their subjective opinions on the subject. Therefore, the following research questions are addressed:

1. To what extent do university students perceive the use of Google Translate as an aid in their language learning?

2. What problems do university students encounter while using Google Translate?

3. What are their solutions when university students face those problems?

\section{$2 \quad$ Literature review}

\subsection{Computer-assisted language learning (CALL)}

Computer-assisted language learning (CALL) is a term used to describe an interactive approach between a learner and a computer that is used to aid in the acquisition of the second language [4][5][6]. According to Beatty [7], computer-assisted language learning (CALL) is the process of using computers to improve a learner's language abilities. One of the many meanings of CALL, according to Levy [8], is seeking for and studying PC applications in language teaching and realizing. The study discovered that CALL is more feasible than traditional learning methods [9][10][11].

\subsection{Mobile-assisted language learning (MALL)}

Chickering and Ehrmann [12] established the term MALL (mobile-assisted language learning) to describe the remarkable development of mobile phones. MALL is 
a technique of language learning that employs portable mobile devices such as smartphones, tablets, and smartphone applications as learning and educational tools for learners via the online platform [13][14][15][16][17]. Many studies have demonstrated that MALL has a good effect on helping learners develop their language abilities, particularly their English vocabulary [18][19][20]. Aside from that, it assists the development of listening, reading comprehension, and writing abilities [21][22] [23][24]. This implies that MALL apps may be utilized as an effective mobile language learning tool [25][26][27][28][29].

\subsection{Machine Translation (MT)}

Machine Translation (MT) is one of the various software kinds used to transform a source language into a destination language. With the initial effort at automated translation in the 1940s, MT researchers went on a road comparable to that of computer scientists [30]. MT is the primary step toward extracting information from large amounts of foreign material and analyzing it later [31] or helps with literature translation [62] and English long and short sentences [64]. According to Irfan [32], MT is also known as automated translation while Artificial Intelligence (AI) is an area of research. Moreover, GT is a type of computer program that transfers text from one language to another without the aid of a translator [33][34][35]. Sukkhwan [2] noted that there are various viable MT providers as of the date of writing, including Bing Translator, Yahoo Babel Fish, and Google Translate. Millions of individuals have used the online machine translation buttons on a daily basis. The bulk of those clicks will be on free online MT engines, notably those associated with major search engines above [36].

\subsection{Google Translate (GT)}

Google Translate (GT), a significant member of the Google organization, is a free online translation assistance tool for instantly translating words, phrases, or even web pages [37][38][39][40][41][42]. GT is accessible via two platforms: the web interface and mobile applications (Android and iOS) [37][39][42]. GT is based on Statistical Machine Translation, which means that instead of aiming for word-for-word translation, the system calculates the probabilities of various translations of a phrase being correct. Google Translate allows users to enter the source language in a variety of ways, including using a virtual keyboard, voice recognition, handwriting, the complete document, or the entire uploaded file. Users can also translate text using graphics or photos [40].

\subsection{The effects of CALL and MALL on learning}

Derakhshan, Salehi, and Rahimzadeh [43] claimed communicative CALL was introduced in the 1970s and 1980s, with personal computers replacing mainframe computers. On personal computers, certain programs were designed to aid in the learning process. Integrative CALL, which first appeared in the 1990s, is the most modern 
approach. Its resources were designed to leverage computers and software programs to put learning ideas into practice. As a result, CALL materials facilitate learners' interaction and use of language. MALL, according to Miangah [44], is a brilliant solution for overcoming time and location constraints when learning a language. Teachers might use audio or video chats to provide learning materials to their students and collect feedback, making it more efficient for both teachers and students. Thouësny and Bradley [45] said MALL helps learners enhance language abilities, has no time constraints (may be practiced at any time), and motivates learners, especially it improves students' learning behaviors, provides a good opportunity for EFL learners to practice the English language both inside and outside the classroom, and boosts students' language skills [9][46] [63].

\subsection{Previous studies on the use of Google Translate}

Learners use GT as a supplemental tool for learning languages [39]. However, participants believed they were unable to translate idioms or proverbs, enhance their speaking and language abilities, and must rely on the Internet to get GT, particularly when they are unsure about its accuracy [38][39][47][48][49][50].

Brahmana, Sofyan and Putri [47] used the descriptive qualitative technique to analyze the challenges of GT. The findings of the study revealed that students frequently had problems with word accuracy and sentence structure. They also cited selfcorrecting the Google Translate outcomes and evaluating the meaning of the translated words on a regular basis as effective solutions to those problems. Besides, students who had inadequate English skills were becoming increasingly reliant on GT [1][51]. In contrast, other studies demonstrated that the quality of GT translations was superior to the quality of learner translations [1][48][51].

\subsection{Conceptual framework}

Researchers have identified the benefits of computer-assisted MT in language learning since the 1980s (CALL). The purpose of this study was to show how MT could be used as a MALL tool in foreign language classes [52]. Google Translate, according to Tumbal, Liando, and Olii [53], has become a well-known machine translation service that has been used by people all over the world. Google Translate is a popular engine because of its easy accessibility, lack of cost, and speedy performance. In order to obtain insight into how students felt about using technology tools to assist them in performing the translation job, their perceptions of the use of Google Translate were also assessed [54]. Google Translate was a tool that could help learners enhance their language learning skills. This translation machine, however, was not thorough. The Google version was not a reliable source because it had a number of problems, especially grammatical errors. Nonetheless, Google Translate could help students improve their language skills [55]. As a result, supplying solutions was required to ensure the quality of its output. The solutions were based on Garcia's [56] with three tactics for using GT to improve learner language learning: pre-editing, post-editing, and selective use. 


\section{$3 \quad$ Methodology}

\subsection{Participants}

The total number of participants was 250 university students at a private educational institution in Vietnam. All of the participants were aged from 18-24, who had experiences using Google Translate for learning purposes, in which 15 students were chosen to join the interviews based on their using frequency and perceptions of Google Translate.

\subsection{Instruments}

The research data were collected through a 5-point Likert-scale questionnaire of 40 questions that were adapted from previous authors [2][49][57][58][59] and semistructured interviews. The questionnaire applied the 5-point Likert scale [60] to investigate the students' perceptions on the use of Google Translate, particularly the common problems, and their proposed solutions based on the research questions of this study. Participants showed their level of agreement with a value from 1 to 5, accordingly "strongly disagree", "disagree", "neutral", "agree", and "strongly agree". Furthermore, to explore the depth of common problems and recommended solutions from students' using Google Translate, semi-structured interviews were conducted with 15 participants.

\subsection{Data collection and analysis}

An important part of this study was the development of a pilot study that was used to analyze the sample responses of 30 students (accounting for about $12 \%$ of the total of 250) who had experience in using Google Translate to check for the reliability of the questionnaire before submission for data collection and analysis. The reliability of the questionnaire was measured by using International Business Machines Corporation Statistical Package for the Social Sciences (IBM SPSS) Statistics version 25. The Cronbach's Alpha result of the questionnaire $(\alpha=0.958)$ was considered reliable.

Researchers delivered the information sheet and consent form to participants on Google Forms before asking the participants to complete the online survey and participating in the interviews to tell them about the nature and scope of the study.

The questionnaire consisting of 40 questions (28 questions about the use of Google Translate, 6 questions about problems, and 6 questions about solutions) was sent to students of different majors to research their perceptions on the use of Google Translate in learning languages. After receiving the responses from students, the researchers chose 15 students among participants who achieved a high mean value for individual interviews on the platform of Google Meet. The interviews were recorded and manually coded and transcribed by thematic interview protocols. 


\section{$4 \quad$ Results}

\subsection{Results from the questionnaire}

Participants answered a questionnaire about students' perceptions of using Google Translate. In the data analysis, the questionnaire's descriptive statistics included overall averages and standard deviations about students' perceptions of Google Translate, namely problems and solutions.

As indicated in Table 1, the overall mean score of the participants who completed the questionnaire was $3.66(\mathrm{M}=3.66, \mathrm{SD}=0.54)$. In addition, the result for a Onesample t-test indicated that there was a statistically significant difference in the mean score between 3.66 and $3.0(\mathrm{t}=19.270, \mathrm{p}=0.000)$ (see in Table 2). As a result, the computed mean score was higher than the average mean scores of the 5-point Likert scale $(M=3.00)$. Hence, students' objective perceptions about Google Translate were at an above-average level. However, the student's perception of the problems in using Google Translate $(\mathrm{M}=3.94, \mathrm{SD}=0.70)$ was at a high level and their perception of the solutions to solve those problems $(\mathrm{M}=3.89)$ was at a rather average level.

Table 1. Mean scores of participants' perceptions

\begin{tabular}{|l|c|c|c|}
\hline \multicolumn{1}{|c|}{ Domains } & N & Mean(M) & SD \\
\hline Use of GT & 250 & 3.56 & .59 \\
\hline Problems of GT & 250 & 3.94 & .70 \\
\hline Solutions of GT & 250 & 3.89 & .74 \\
\hline General Means & 250 & 3.66 & .54 \\
\hline
\end{tabular}

Table 2. One-sample t-test of general means (Test value $=3$ )

\begin{tabular}{|l|c|c|c|c|c|c|}
\hline & \multirow{2}{*}{$\mathbf{t}$} & df & $\begin{array}{c}\text { Sig. } \\
\text { (2-tailed) }\end{array}$ & $\begin{array}{c}\text { Mean } \\
\text { difference }\end{array}$ & 95\% Confidence Interval of the Difference \\
\cline { 5 - 7 } & & & .000 & .66600 & Lower & Upper \\
\hline General Means & 19.270 & 249 & .5979 & .7341 \\
\hline
\end{tabular}

The analysis of participants' perceptions on the use of Google Translate. As seen in Table 1, the entire mean score of the participant's perceptions of the use of Google Translate was $3.56(\mathrm{M}=3.56, \mathrm{SD}=0.59)$. Besides, the result for a One-sample $\mathrm{t}$-test showed that there was a statistically significant difference in the mean score between 3.56 and $3.0(\mathrm{t}=14.805, \mathrm{p}=0.000)$ (see in Table 3$)$. It means the students' perceptions of the use of Google Translate was only an above-average level.

Table 3. One-sample t-test of perceptions on the use of Google Translate (Test value $=3$ )

\begin{tabular}{|l|c|c|c|c|c|c|}
\hline & \multirow{2}{*}{$\mathbf{t}$} & df & $\begin{array}{c}\text { Sig. } \\
(\text { 2-tailed })\end{array}$ & \multirow{2}{*}{ Mean difference } & 95\% Confidence Interval of the Difference \\
\cline { 5 - 7 } & & & & Lower & Upper \\
\hline Use of GT & 14.805 & 249 & .000 & .55843 & .4841 & .6327 \\
\hline
\end{tabular}


As the results in Table 4, Question $26(\mathrm{M}=4.50, \mathrm{SD}=0.767)$, Question $23(\mathrm{M}=$ $4.34, \mathrm{SD}=0.811)$, and Question $25(\mathrm{M}=4.16, \mathrm{SD}=0.863)$ gained a significantly higher mean score than the other statements. In addition, the result for a One-sample t-test showed that there was a computably significant difference in the mean score between these mean scores and $4.0(\mathrm{p}<0.05)$. It pointed out the perceptions of Google Translate those multiple languages translation, ease of use, and save time are at a rather high level, thus, these results were suitable with the findings of Septiadi [1], Maulidiyah [38], Thouësny and Bradley [45], Krisnawati [50], Chandra and Yuyun [51], and Tsai [61]. Besides, Question $20(\mathrm{M}=4.12, \mathrm{SD}=1.098)$, and Question 24 (M $=4.03, \mathrm{SD}=0.983)$ had slightly higher results than the others. The result for a Onesample t-test demonstrated that there was not a systematically significant difference in the mean score between these mean scores and 4.0 ( $p>0.05$ ), indicating that Google Translate quick translation and help students for improving pronunciation were at a high level. It was the same with the findings of Habeeba [48] and Krisnawati [50] related to useful features of Google Translate.

Table 4. Mean score of perceptions on the use of Google Translate

\begin{tabular}{|l|c|c|}
\hline \multicolumn{1}{|c|}{ Items } & Mean (M) & SD \\
\hline Question 6: Google Translate makes me lazy to think & 2.41 & 1.278 \\
\hline Question 20: Google Translate can translate texts quickly & 4.12 & 1.098 \\
\hline $\begin{array}{l}\text { Question 22: Poor students depend more on GT in learning English rather than } \\
\text { average and good students }\end{array}$ & 2.34 & .903 \\
\hline Question 23: Google Translate is easy to use & 4.34 & .811 \\
\hline Question 24: Google Translate can help students to pronounce words & 4.03 & .983 \\
\hline Question 25: Google Translate can help students save time & 4.16 & .863 \\
\hline Question 26: Google Translate can translate various languages & 4.50 & .767 \\
\hline Use of GT & 3.56 & .60 \\
\hline
\end{tabular}

In contrast, Question $22(\mathrm{M}=2.34, \mathrm{SD}=0.903)$ and Question $6(\mathrm{M}=2.41, \mathrm{SD}=$ 1.278 ) were the lowest mean scores than other items. The result from a One-sample ttest demonstrated that there was a statistically significant difference in the mean score between these mean scores and $2.0(\mathrm{p}<0.05)$. The result indicated the poor students did not depend on Google Translate a lot and Google Translate did not make students lazy to think, these problems were only at a low level, which was in line with the results of Esteban, Palawatwichai, and Inpaen [3]. Also, the remaining perceptions on using Google Translate were also at a normal level.

The analysis of participants' perceptions on the problems. As the results in Table 6, the mean score of participants' perceptions on the problems in using the Google Translate process was $3.94(\mathrm{M}=3.94, \mathrm{SD}=0.70)$. Also, the result for a One-sample ttest demonstrated that there was not a statistically significant difference in the mean score between 3.94 and $4.0(t=-1.303, p=0.194)$ (see in Table 5). The measured mean score had the result approaching a high level of the 5-point Likert scale $(M=4.00)$. Therefore, the result showed problems that participants faced at the usual frequency. 
Table 5. One-sample test of problems (Test value $=4)$

\begin{tabular}{|l|c|c|c|c|c|c|}
\hline & \multirow{2}{*}{$\mathbf{t}$} & df & \multirow{2}{*}{$\begin{array}{c}\text { Sig. } \\
\text { (2-tailed) }\end{array}$} & \multirow{2}{*}{$\begin{array}{c}\text { Mean } \\
\text { difference }\end{array}$} & 95\% Confidence Interval of the Difference \\
\cline { 5 - 7 } & & & .194 & -.05800 & Lower & Upper \\
\hline Problems & -1.303 & 249 & .1457 & .0297 \\
\hline
\end{tabular}

Table 6. Mean score of problems on the use of Google Translate in learning

\begin{tabular}{|l|c|c|}
\hline \multicolumn{1}{|c|}{ Items } & Mean (M) & SD \\
\hline Question 29: GT gives some grammatical errors from the translation results & 4.30 & .83 \\
\hline Question 31: Sometimes GT's outcomes are difficult to understand & 4.36 & .89 \\
\hline Question 33: GT makes confused about the meanings of words & 4.11 & .90 \\
\hline Question 35: GT is unable to translate proverbs and idioms & 3.96 & 1.02 \\
\hline Question 37: Using GT's translation results is plagiarism & 3.18 & 1.14 \\
\hline Question 39: I paraphrase the translation results from GT & 3.73 & 1.29 \\
\hline Problems & 3.94 & .70 \\
\hline
\end{tabular}

In Table 6, Question $31(\mathrm{M}=4.36, \mathrm{SD}=0.89)$ and Question $29(\mathrm{M}=4.30, \mathrm{SD}=$ 0.83 ) had higher mean scores than the remaining statements. Based on a One-sample t-test, these mean scores had a mathematically significant difference in the mean score with $4.0(\mathrm{p}<0.05)$. It indicated that the problem of Google Translate giving some wrong grammar and its incorrect outcome was at a fairly high level, which was in line with the findings of Bahri \& Mahadi [39], Brahmana, Sofyan and Putri [47], and Zulkifli [49] related to Google Translate giving some grammar errors and misunderstanding about its output. However, Question $39(\mathrm{M}=3.73, \mathrm{SD}=1.29)$ and Question $37(\mathrm{M}=3.18, \mathrm{SD}=1.14)$ obtained a slightly lower mean score than others. There was a computably significant difference in the mean value with $3.0(\mathrm{p}<0.05)$ from the result of a One-sample t-test. It showed that the difficulty to access Google Translate and the plagiarism of the translation results were only at a pretty average level, participants did not often face these problems in using the Google Translate process.

The analysis of participants' perceptions on the solutions. In Table 8 , the overall mean value of solutions to solve the popular problems in using the Google Translate process $(\mathrm{M}=3.89, \mathrm{SD}=0.74)$ was moderately higher than the average level of the 5-point Likert scale $(\mathrm{M}=3.00)$. There was a statistically remarkable difference in the mean value between 3.89 and $3.0(\mathrm{t}=18.951, \mathrm{p}=0.000)$ (see in Table 7). Therefore, solutions that students utilize to solve the problems in the use of Google Translate only at a pretty average level.

Table 7. One-sample test of solutions (Test value $=3$ )

\begin{tabular}{|l|c|c|c|c|c|c|}
\hline & \multirow{2}{*}{$\mathbf{t}$} & df & \multirow{2}{*}{$\begin{array}{c}\text { Sig. } \\
\text { (2-tailed) }\end{array}$} & \multirow{2}{*}{ Mean difference } & \multicolumn{2}{|c|}{ 95\% Confidence Interval of the Difference } \\
\cline { 5 - 7 } & & & .89200 & Lower & Upper \\
\hline Solutions & 18.951 & 249 & .000 & .7993 & .9847 \\
\hline
\end{tabular}


Table 8. Mean score of solutions on the use of Google Translate in learning

\begin{tabular}{|l|c|c|c|}
\hline \multicolumn{1}{|c|}{ Items } & N & Mean (M) & SD \\
\hline Question 30 & 250 & 3.94 & .96 \\
\hline Question 32 & 250 & 3.62 & 1.10 \\
\hline Question 34 & 250 & 3.99 & 1.02 \\
\hline Question 36 & 250 & 3.92 & 1.07 \\
\hline Question 38 & 250 & 3.91 & .94 \\
\hline Question 40 & 250 & 3.98 & 1.26 \\
\hline Solutions & 250 & 3.89 & .74 \\
\hline
\end{tabular}

According to Table 8, Question $34(\mathrm{M}=3.99, \mathrm{SD}=1.02)$ and Question $40(\mathrm{M}=$ 3.98, $\mathrm{SD}=1.26$ ) had the highest mean value in all statements. As the result of the Onesample t-test, Question 34 and Question 40 did not have an analytically remarkable difference in the mean value with 4.0 ( $>>0.05)$, showing the perceptions on solutions to resolve the problems in using Google Translate was at a high level. To solve Google Translate making participants confused about the meaning of words, participants often used the dictionary to check the meaning of words, it was the same with findings of Chandra, and Yuyun [51]. Besides, almost all participants installed Google Translate into their mobile devices to be easy to access without the Internet (offline). Conversely, Question $32(\mathrm{M}=3.62, \mathrm{SD}=1.10)$ had a lower value than the other items. It showed the solution of asking for the others' help was only a quite average level because there was an analytically significant difference in the mean value between 3.62 and $3.0(\mathrm{p}<0.05)$ from the results of a One-sample t-test. It meant participants were less used to it than other solutions.

\subsection{Results from the interviews}

The interview showed that all the interviewees (100\%) agreed that they considered GT as a tool to translate, with learning purpose. The participants 12 and 7 mentioned that:

"Google Translate was a tool to support learning such as language learning, translating from one language to another quickly and conveniently...especially for learning English."

$100 \%$ of the interviewees said that GT was used to check unfamiliar words. Participants 6 and 14 said that:

"I use Google Translate for learning purposes such as translating complicated sentences or writing essays and for learning purposes such as looking up unknown words."

The majority of participants rated their satisfaction with GT's results (about 67\%), but the result still had some problems. Participants said that GT had some errors in vocabulary, grammar, and semantics. Participant 4 said that:

"Sometimes I'm not satisfied with the translation results. Google Translate translates wrong grammar, vocabulary, and the meaning of the sentence." 
In terms of semantics, $70 \%$ of the total participants said that mistranslation of the sentences or results from the translation was confusing. Participant 8 said:

"Translating word-by-word will have a different meaning, leading to the wrong purpose. Google Translate results are not as expected and confusing. Vocabulary is chaotic, and grammar is automatically omitted."

About $67 \%$ of the participants used other electronic dictionaries to check vocabulary or incorrect words after receiving Google Translate outputs, such as Cambridge, Oxford, and TFlat. Participants 13 and 12 mentioned:

"I use Cambridge, Oxford to correct problems related to vocabulary or I use TFlat to recheck GT's incorrect words."

The interview dedicated 5 interviewees out of 15 agreed that using other applications or software, such as Grammarly to fix grammar mistakes of Google Translate outcomes. Participant 6 said that:

"I use Grammarly to correct its errors. On the Grammarly page, it will show a yellow or red underline in order to suggest correct words and basic grammar for editing."

However, interviewees suggested several solutions that were different from the others such as using suggestions from Google Translate, checking on grammar books, checking grammar on QuillBot (another application), and rewriting sentences better than Google Translate. Participant 9 said:

"If I have a grammatical error, I use the Grammarly page to recheck the grammar, then go to QuillBot web to check the grammar one more time and rewrite the sentence to a better level, then select academic words to replace."

In another question, the interview revealed that most of the participants $(70 \%)$ agreed that they were still using Google Translate because of its convenient features, such as being free, popular, and quick. Most of them stated that they used Google Translate because it's convenient, fast, and completely free.

\section{Discussion}

The study's goal was to look at students' perceptions of utilizing Google Translate for learning at a private university. The researchers discovered that students' perceptions of using Google Translate were generally above average after analyzing the data. Three aspects impacted students' perceptions: the use of Google Translate, general problems, and the recommended solutions. According to the findings, students had a favorable opinion on the use of Google Translate for general learning purposes, which was similar to the findings of Habeeba and Muhammedb [48], and Chandra \& Yuyun [51].

The first aspect was that students' perceptions of using Google Translate were not high but above average, although they were above average $(\mathrm{M}=3.56, \mathrm{SD}=0.60)$. This section contains 28 questions in which students agreed that Google Translate could translate into a variety of languages. Lower-achieving students, on the other hand, were less reliant on Google Translate in their learning than higher-achieving students. 
The second element was students' perceptions of the problems in using Google Translate $(\mathrm{M}=3.94, \mathrm{SD}=0.70)$. Grammar, vocabulary, semantics, idioms, and proverbs were some of the most common problems that students confronted. The first aspect that students were most interested in was semantics. The majority of students believed that Google Translate's results was usually confusing and incorrect, so this result was equivalent to Habeena and Muhammedb [48]. Hence, Google Translate was a machine translation, students commonly experienced problems with the grammar of the produced text. These findings are similar to Groves and Mundt [42], and Zukifli [49], who discovered that Google Translate translations might be grammatically incorrect. As a result, the findings might be less precise than those acquired by human translation. Students, on the other hand, did not consider utilizing Google Translate to be plagiarism. According to Septiadi [1], and Habeeba and Muhammedb [48], students had higher trust in Google Translate outputs than in their own handtranslated translations.

Finally, students' solutions while using Google Translate were not high, only rather average $(\mathrm{M}=3.89, \mathrm{SD}=0.74)$. According to the study's findings, students utilized a range of tactics to enhance their translation outputs, including asking for help from others and using a dictionary or other tools to double-check their work, particularly those who used alternative dictionaries instead of Google Translate. Sukkhwan's [2] and Maulidiyah's [38] results were equivalent. In addition, the students occasionally sought assistance from others.

In addition, students had a high perception of Google Translate problems and found other support tools to achieve complete translations. This is comparable to the point of view of Esteban, Palawatwichai, and Inpaen [3].

\section{Conclusion}

The findings of the current study indicated that students had positive perceptions on the use of Google Translate in learning languages at their private university, especially the problems when using Google Translate were very regular encounters and the proposed solutions were pretty at an average level. Students utilized Google Translate as an aid to learning, especially the language purpose because of its convenient functions such as translating multi-languages, saving time, using it easily, and improving pronunciation. Despite its benefits for learners, several problems appeared in using the process. Students regularly encountered inaccurate grammar and semantics, sometimes it made learners confused about the meanings of words. Therefore, students found that they had to have distinct solutions to resolve the inaccurate outcomes from Google Translate. Specifically, the majority of students used the dictionary or other translation applications, and the assistance of their acquaintance to examine the vocabulary and semantics. Importantly, students applied their background knowledge to ensure its outcomes when using Google Translate as an aid.

Conducting under the preparation and consultation based on conceptual frameworks from previous research, the study had some limitations in collecting data, including the small size of participants, short time duration, and the study process dur- 
ing the Covid-19 lockdown. Moreover, students were in various majors, thus, they used Google Translate at varying levels. This directly affected the student's perceptions of using Google Translate for learning purposes.

The researchers trust that the study is able to be a serviceable reference for others to consider using Google Translate as an aid to learning in general and language acquisition in particular. The study provides greater visibility into Google Translate in learning, including the positive and negative aspects of what Google Translate offers. Therefore, students have perceptions of the duality of Google Translate to take advantage of it in learning and not be affected by their learning habits. In addition, Google Translate would be a valuable learning tool to help students understand more of a text in different fields of study.

\section{$7 \quad$ References}

[1] Septiadi, A. R. (2019). English freshman students' attitudes towards the use of Google Translate at IAIN Palangka Raya. [Doctoral dissertation, IAIN Palangka Raya]. Digital library IAIN Palangka Raya. http://digilib.iain-palangkaraya.ac.id/id/eprint/2522

[2] Sukkhwan, A. (2014). Students' attitudes and behaviors towards the use of Google Translate. [Doctoral dissertation, Prince of Songkla University]. PSU Knowledge Bank. https://k b.psu.ac.th/psukb/bitstream/2010/9459/1/387714.pdf

[3] Esteban, R. H., Palawatwichai, N., \& Inpaen, W. (2018). A study of students' ways \& perspectives towards the use of Google Translate. International Conference on English Language Studies 2018. Suranaree University of Technology, 22-32. http://soctech.sut.ac.th/fl/ conference/wp-content/uploads/2018/08/ICLES-2018-Abstract-Program.pdf

[4] Levy, M., \& Hubbard, P. (2005). Why call CALL "CALL"? Computer Assisted Language Learning. Routledge, 18(3), 143-149. https://doi.org/10.1080/09588220500208884

[5] Gündüz, N. (2005). Computer Assisted Language Learning. Journal of Language and Linguistic Studies, 1 (2), 193-214. https://www.jlls.org/index.php/jlls/article/view/16

[6] Felix, U. (2004). A multivariate analysis of secondary students' experience of web-based language acquisition. In A. Boulton (Ed.). ReCALL (1st ed., 237-249). Cambridge University Press. https://doi.org/10.1017/S0958344004001715

[7] Beatty, K. (2013). Teaching \& inquiry: Computer-assisted language learning (2nd ed.). Routledge. https://doi.org/10.4324/9781315833774

[8] Levy, M. (1997). Computer-assisted language learning: Context and conceptualization (1st ed.). Oxford University Press.

[9] Al-Khayyat, A. S. J. (2015). The effect of CALL proposed program on university students' achievement in English. Arab World English Journal (AWEJ), Special Issue on CALL No.2, 183-194. https://doi.org/10.2139/ssrn.2843988

[10] Nachoua, H. (2012). Computer-assisted language learning for improving students' listening skills. Procedia-Social and Behavioral Sciences. ScienceDirect, 69, 1150-1159. https:// doi.org/10.1016/j.sbspro.2012.12.045

[11] Jiang, W., \& Ramsay, G. (2005). Rapport-building through CALL in teaching Chinese as a foreign language: An exploratory study. Language Learning \& Technology, 9(2), 47-63. https://www.lltjournal.org/item/2506

[12] Chickering, A. W., \& Ehrmann, S. C. (1996). Implementing the seven principles: Technology as lever. AAHE Bulletin, 49, 3-6. https://sphweb.bumc.bu.edu/otlt/teachingLibrary/ Technology/seven_principles.pdf 
[13] Loewen, S., Crowther, D., Isbell, D. R., Kim, K. M., Maloney, J., Miller, Z. F., \& Rawal, H. (2019). Mobile-assisted language learning: A Duolingo case study. In A. Boulton (Ed.). ReCALL (1st ed., 293-311). https://doi.org/10.1017/s0958344019000065

[14] Rocca, S. (2018). Introducing the special issue: Mobilizing language learning in the $21 \mathrm{st}$ century. Languages: An international, open access journal. Multidisciplinary Digital Publishing Institute, 3(1), 1-3. https://doi.org/10.3390/languages3010002

[15] Godwin-Jones, R. (2017). Smartphones and language learning. Language Learning \& Technology, 21(2), 3-17. https://dx.doi.org/10125/44607

[16] Davie, N., \& Hilber, T. (2015, March 14-16). Mobile-Assisted Language Learning: Student attitudes to using smartphones to learn English vocabulary [Paper presentation]. International Association for Development of the Information Society (IADIS) International Conference on Mobile Learning, Madeira, Portugal.

[17] Kukulska-Hulme, A., \& Shield, L. (2008). An overview of mobile assisted language learning: From content delivery to supported collaboration and interaction. In A. Boulton (Ed.). ReCALL (1st ed., 271-289). Cambridge University Press. https://doi.org/10.1017/S095834 $\underline{4008000335}$

[18] Marzban, A., \& Nafarzadehnafari, F. (2018). The effect of interventionist classroom vs. MALL dynamic assessment on EFL learners' vocabulary learning. Applied Linguistics Research Journal, 2(3), 58-66. https://doi.org/10.147444/alrj.2018.36844

[19] Duman, G., Orhon, G., \& Gedik, N. (2014). Research trends in mobile assisted language learning from 2000 to 2012. In A., Boulton (Ed.). ReCALL (1st ed., 197-216). Cambridge University Press. https://doi.org/10.1017/s0958344014000287

[20] Kim, H. S. (2011). Effects of SMS text messaging on vocabulary learning. Korean Open Access Journals, 14(2), 159-180. https://doi.org/10.15702/mall.2011.14.2.159

[21] Gharehblagh, N. M., \& Nasri, N. (2020). Developing EFL elementary learners' writing skills through mobile-assisted language learning (MALL). Teaching English with Technology, 20(1), 104-121. http://cejsh.icm.edu.pl/cejsh/element/bwmeta1.element.desklightc347b875-c759-48ab-92b1-4677b333d420

[22] Al-Hamad, R. F., Al-Jamal, D., \& Bataineh, R. F. (2019). The effect of MALL instruction on teens' writing performance. Digital Education Review, 35, 289-298.

[23] Hsu, C. K. (2014). Learning motivation and adaptive video caption filtering for EFL learners using handheld devices. In A. Boulton (Ed.). ReCALL (1st ed., 84-103). Cambridge University Press. https://doi.org/10.1017/s0958344014000214

[24] Huang, C. C., \& Sun, P. C. (2010). Using mobile technologies to support mobile multimedia English listening exercises in daily life. In Smys, S., Bestak, R., Chen, JLZ, \& Kotuliak, I. (Eds.). International conference on computer and network technologies in education (1st ed.).

[25] Gonulal, T. (2019). The use of Instagram as a Mobile-Assisted Language learning tool. Contemporary Educational Technology, 10(3), 309-323. https://doi.org/10.30935/cet.5901 $\underline{08}$

[26] Morgana, V. (2019). A review of MALL: From categories to implementation. The case of Apple's iPad. The EuroCALL Review, 27(2), 1-12. Universitat Politecnica de Valencia. https://doi.org/10.4995/eurocall.2019.11024

[27] Helwa, H. (2017). Using mobile assisted language learning (MALL) approach for developing prospective teachers' EFL listening comprehension skills and vocabulary learning. Journal of Research in Curriculum Instruction and Educational Technology, 3(4), 133176. https://doi.org/10.21608/jrciet.2017.24440

[28] Tayan, B. M. (2017). Students and teachers' perceptions into the viability of mobile technology implementation to support language learning for first year business students in a 
Middle Eastern university. Journal of International Education and Literacy Studies, 5(2), 74-83. https://doi.org/10.7575/aiac.ijels.v.5n.2p.74

[29] Stockwell, G. (2008). Investigating learner preparedness for and usage patterns of mobile learning. In A. Boulton (Ed.) ReCALL (1st ed., 253-270). Cambridge University Press. https://doi.org/10.1017/S0958344008000232

[30] Bott, M. F. (1969). Introduction to computational linguistics. In K., Börjars, H. D., Hoop, A. Ledgeway \& M. V. Oostendorp (Eds.). Journal of Linguistics (1st ed.,190-192). Cambridge University Press. https://doi.org/10.1017/S0022226700002206

[31] Koehn, P. (2009). Statistical machine translation (1st ed.). Cambridge University Press. https://doi.org/10.1017/CBO9780511815829

[32] Irfan, M. (2017). Machine Translation [Master's thesis, Bahria University]. https://www. researchgate.net/publication/30730405_Machine_Translation

[33] Munpru, S., \& Wuttikrikunlaya, P. (2013). A survey of online tools used in English - Thai and Thai - English translation by Thai students. Foreign Language Learning and Teaching International Conference. Language Institute of Thammasat University, 69-86. http:// www.litu.tu.ac.th/journal/FLLTCP/Proceeding/069.pdf

[34] Korosec, M. K. (2011). The internet, Google Translate and Google Translator Toolkit. Nuisance or Necessity in Translator Training? HAL Archives-ouvertes. https://hal.archives -ouvertes.fr/hal-02495846

[35] Hutchins, W. J., \& Somers, H. L. (1992). An introduction to the machine translation (1st ed.). Academic Press.

[36] Garcia, I., \& Pena, M. I. (2011). Machine translation-assisted language learning: writing for beginners. Computer Assisted Language Learning. Routledge, 24(5), 471-487. https:// doi.org/10.1080/09588221.2011.582687

[37] Google Translate (2021). Google Translate Help. Google Help. https://support.google.com /translate

[38] Maulidiyah, F. (2018). To use or not to use Google Translate in English language learning. Jurnal Linguistik Terapan, 8(2), 1-7. http://jlt-polinema.org/?p=996

[39] Bahri, H., \& Mahadi, T. S. T. (2016). Google Translate as a supplementary tool for learning Malay: A case study at Universiti Sains Malaysia. Advances in Language and Literary Studies, 7(3), 161-167. https://doi.org/10.7575/aiac.alls.v.7n.3p.161

[40] Medvedev, G. (2016). Google Translate in teaching English. Journal of Teaching English for Specific and Academic Purposes, 4(1), 181-193. http://espeap.junis.ni.ac.rs/index.php/e speap/article/view/318

[41] Turovsky, B. (2016, April 28). Ten Years of Google Translate. Google. https://www.blog. google/products/translate/ten-years-of-google-translate/

[42] Groves, M., \& Mundt, K. (2015). Friend or foe? Google Translate in language for academic purposes. English for Specific Purposes. ScienceDirect, 37, 112-121. https://doi.org/10. 1016/i.esp.2014.09.001

[43] Derakhshan, A., Salehi, D., \& Rahimzadeh, M. (2015). Computer-assisted language learning (CALL): Pedagogical pros and cons. International Journal of English Language and Literature Studies, 4(3), 111-120. https://doi.org/10.18488/journal.23/2015.4.3/23.3.111.1 $\underline{20}$

[44] Miangah, T. M., \& Nezarat, A. (2012). Mobile-assisted language learning. International Journal of Parallel, Emergent and Distributed Systems, 3(1), 309-319. https://doi.org/10.51 21/ijdps.2012.3126

[45] Thouësny, S., \& Bradley, L. (2011). Second language teaching and learning with technology: Views of emergent researchers (1st ed.). https://doi.org/10.14705/rpnet.2011.9781908 $\underline{416001}$ 
[46] Soleimani, E., Ismail, K., \& Mustaffa, R. (2014). The acceptance of mobile assisted language learning (MALL) among post graduate ESL students in UKM. Procedia-Social and Behavioral Sciences. ScienceDirect, 118, 457-462. https://doi.org/10.1016/j.sbspro.2014.0 $\underline{2.062}$

[47] Brahmana, C. R. P. S., Sofyan, R., \& Putri, D. M. (2020). Problems in the application of Google Translate as a learning media in translation. Language Literacy: Journal of Linguistics, Literature, and Language Teaching, 4(2), 384-389. https://doi.org/10.30743/11.v4i $\underline{2.2893}$

[48] Habeeba, L. S., \& Muhammedb, M. R. (2020). Investigating the effectiveness of Google Translate among Iraqi students. International Journal of Innovation, Creativity, and Change, 12(12), 104-116. https://www.ijicc.net/images/vol12/iss12/121231_Habeeb_2020 E_R.pdf

[49] Zulkifl, S. R. M. (2019). A qualitative study: The use of Google Translate among English Education Department students [Undergraduate thesis, Universitas Muhammadiyah Yogyakarta]. UMY Repository. http://repository.umy.ac.id/handle/123456789/30674

[50] Krisnawati, N. L. P. (2017). The role of Google Translate for Indonesian EFL learners. Proceedings of International Seminar on English Language and Teaching, Fakultas Bahasa dan Seni Universitas Negeri Padang, 5, 138-143. http://ejournal.unp.ac.id/index.php/selt/ar $\underline{\text { ticle/view/7996 }}$

[51] Chandra, S. O., \& Yuyun, I. (2018). The use of Google Translate in EFL essay writing. LLT Journal: A Journal on Language and Language Teaching, 21(2), 228-238. https://doi. org/10.24071/llt.2018.210212

[52] Tuzcu, A. (2021). The impact of Google Translate on creativity in writing activities. Language Education and Technology, 1(1), 40-52. https://langedutech.com/letjournal/index.ph $\mathrm{p} /$ let/article/view/18

[53] Tumbal, S., Liando, N. V. F., \& Olii, S. T. (2021). Students' perceptions toward the use of Google Translate in translating. KOMPETENSI: Jurnal Ilmiah Bahasa dan Seni, 1(2), 313320. http://ejurnal-mapalus-unima.ac.id/index.php/kompetensi/article/view/1853

[54] Chen, C. W. Y. (2020). Using Google Translate is an authentic translation task: The process, refinement efforts and student perceptions. Current Trends in Translation Teaching and Learning E, 7, 213-248. http://www.cttl.org/uploads/5/2/4/3/5243866/cttl e 20207 cheryl_chen_wei-yu.pdf

[55] Zanettin, F. (2009). Corpus-based translation activities for language learners. The Interpreter and Translator Trainer. Routledge, 3(2), 209-224. https://doi.org/10.1080/1750399X .2009 .10798789

[56] Garcia, I. (2010). Is machine translation ready yet? John Benjamins Publishing Company, 22(1), 7-21. https://doi.org/10.1075/target.22.1.02gar

[57] Siregar, M., Panah, E., Jaafar, A., \& Adisaputera, A. (2021). Pre-service teachers' perceptions on 'Google Translate' as a tool for English language learning. TESOL International Journal, 16(6.2), 37-55.

[58] Susanto, R. D. (2017). Students' attitudes towards the use of Google Translate. [Doctoral dissertation, Universitas Kristen Satya Wacana Salatiga]. Digital library Universitas Kristen Satya Wacana Salatiga. https://repository.uksw.edu/handle/123456789/14459

[59] Dewi, M. O. K. (2016). The students' perception on the use of Google Translate in writing analytical exposition text: A study at Sma N 1 Banguntapan [Doctoral dissertation, Sanata Dharma University]. The Repository. https://repository.usd.ac.id/3052/2/111214118 full.p $\underline{\mathrm{df}}$

[60] Likert, R. (1932). A technique for the measurement of attitudes (1st ed.). Archives of psychology. 
[61] Tsai, S. C. (2019). Using Google Translate in EFL drafts: A preliminary investigation. Computer Assisted Language Learning. Routledge, 32(5-6), 510-526. https://doi.org/10.1 $\underline{080 / 09588221.2018 .1527361}$

[62] Omar, A., \& Gomaa, Y. A. (2020). The Machine Translation of Literature: Implications for translation pedagogy. International Journal of Emerging Technologies in Learning (iJET), 15(11), 228-235. https://doi.org/10.3991/ijet.v15i11.13275

[63] Shi, Z., Luo, G., \& He, L. (2017). Mobile-assisted Language Learning using WeChat instant messaging. International Journal of Emerging Technologies in Learning (iJET), 12(02), 16-26. https://doi.org/10.3991/ijet.v12i02.6681

[64] Zhang, T. (2020). Recognition and segmentation of English long and short sentences based on Machine Translation. International Journal of Emerging Technologies in Learning (iJET), 15(01), 152-162. https://doi.org/10.3991/ijet.v14i19.10182

\section{Authors}

Anh Tuan Pham is an English lecturer at English Language Department, FPT University, Can Tho, Vietnam. His research interests are ICT in education, translation and language education.

Y Ngoc Nhu Nguyen is an undergraduate student at English Language Department, FPT University, Can Tho, Vietnam (email: YNNNCA140020@fpt.edu.vn).

Loi Thang Tran is an undergraduate student at English Language Department, FPT University, Can Tho, Vietnam (email: LoiTTCA140280@fpt.edu.vn).

Khang Duy Huynh is an undergraduate student at English Language Department, FPT University, Can Tho, Vietnam (email: KhangHDCA140318@fpt.edu.vn).

Ngan Thi Kim Le is an undergraduate student at English Language Department, FPT University, Can Tho, Vietnam (email: NganLTKCA140364@fpt.edu.vn).

Phuc Trong Huynh is an undergraduate student at English Language Department, FPT University, Can Tho, Vietnam (email: PhucHTCA140452@fpt.edu.vn).

Article submitted 2021-11-09. Resubmitted 2021-12-15. Final acceptance 2021-12-18. Final version published as submitted by the authors. 